\title{
Antiviral and antiparasitic activities of clovamide: the major constituent of Dichrostachys cinerea (L.) Wight et Arn
}

\author{
Reham T. El-Sharawy ${ }^{1,2}$, Ahmed Elkhateeb ${ }^{1 *}$, Mona M. Marzouk ${ }^{1}$, Rasha R. Abd El-Latif ${ }^{1}$, Salah Eldeen Abdelrazig ${ }^{3}$, \\ Mohamed A. El-Ansari ${ }^{1}$ \\ ${ }^{1}$ Department of Phytochemistry and Plant Systematics, National Research Centre, 33 El Bohouth St., Dokki, Giza, Egypt. \\ ${ }^{2}$ Department of Pharmacognosy and Medicinal Plants, Heliopolis university for sustainable development, Cairo, Egypt. \\ ${ }^{3}$ Chemistry Department, University of Western Kordufan, West Kordofan, Sudan.
}

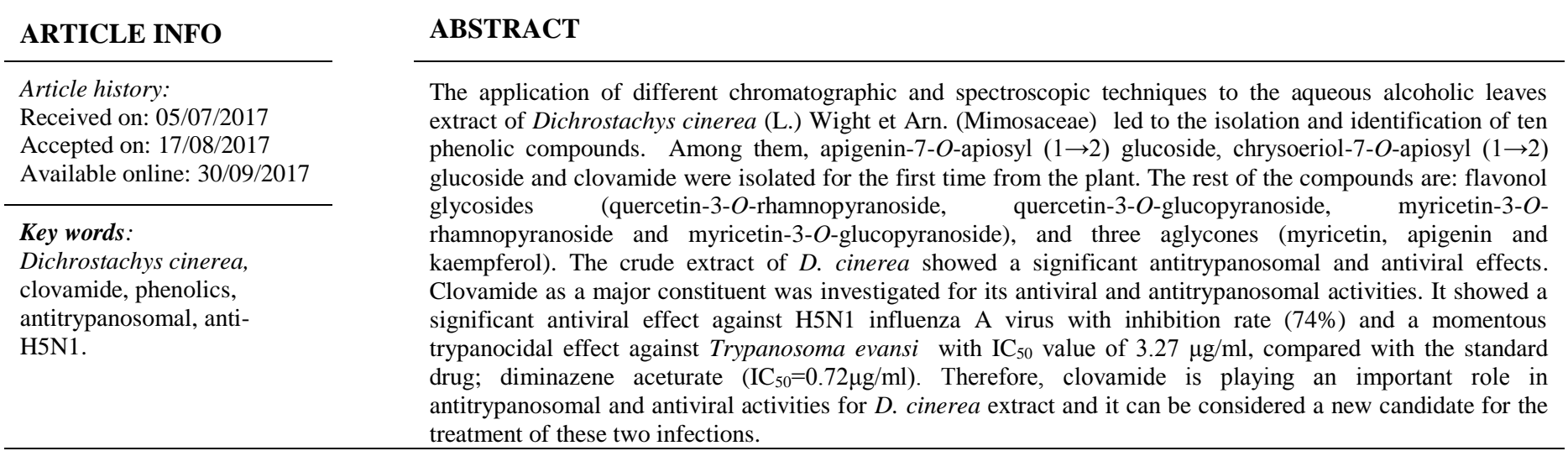

\section{INTRODUCTION}

Dichrostachys cinerea (L.) Wight et Arn. (Mimosaceae) known as Sicklebush, Bell mimosa, Chinese lantern tree or Kalahari Christmas tree, is a semi-deciduous to deciduous fast growing tree, typically grows up to 7 meters in height. It characterized by strong alternate smooth spines (up to 8 $\mathrm{cm}$ long), dark grey-brown fractures on old branches and stems and bark on younger branches (Zeid et al., 2009).

* Corresponding Author

Ahmed Elkhateeb, Department of Phytochemistry and Plant Systematics, National Research Centre, 33 El Bohouth St., Dokki, Giza, Egypt.

E mail: elkhateeb.ahmed@gmail.com,Tel: +201116757520
D. cinerea is one of the very useful wild medicinal plants used in folk medicine across Africa and Asia (AworetSamseny et al., 2011). Its bark is used to prepare concoction for treatment of dysentery, headache and elephantiasis. The root infusions are used to treat gonorrhea coughs, syphilis and sore eye and also used as laxative, anthelmintic and strong diuretic. Leaves are good fodder for domesticated animals and seeds are edible (Neondo et al., 2012). Pharmacological studies on D. cinerea have shown antibacterial, antiviral, antilice, antiplasmodial, and antitrypanosomal effects (Aworet-Samseny et al., 2011; Vijayalakshmi et al., 2010; Atindehou et al., 2004). Phytochemical studies on $D$. cinerea revealed the isolation of various constituents, such as sterols, alkaloids, tannins, triterpenes, polyphenols, phenolic acids, flavonoids (Zeid et al., 2009) and cardiotonic heterosides (Tillement et al., 1977). 
Trypanosoma evansi, an animal-pathogenic protozoan parasite, infects various big animals including buffaloes, camels, equines, cattle, goats, and sheep causing great economic losses in the infected areas, where thousands of animals die from $T$. evansi infections (Luckins 1988). Diminazene aceturate and suramin are the most commonly used drugs for the treatment of $T$. evansi infection. However, they cause severe side effects and the development of drug resistant trypanosomes has occurred in many regions (Elkhateeb et al. 2012).

Influenza, a respiratory disease caused by influenza A viruses, is still one of the major epidemics worldwide that are highly transmissible pathogens for humans and some animals (Droebner et al., 2007). H5N1 is one of the highly pathogenic avian IV strains. It is rarely infected humans and poses a severe threat because of its high pathogenicity (Pleschka et al. 2009). The development of influenza A viruses resistant to antiviral drugs draw attention to the need for other antiviral drugs. Although several antiviral compounds have been developed against influenza virus, they are of limited efficacy due to toxicity and/or the appearance of drug-resistant virus mutants (Droebner et al., 2007).

The crude extract of $D$. cinerea showed a remarkable antitrypanosomal and antiviral effects (Atindehou et al., 2004; Aworet-Samseny et al., 2011). Therefore, it was of a great importance to check the antitrypanosomal and antiviral activities of its major constituents which my lead to an alternative drug with least side effects and higher efficacy for the treatment of T. evansi and H5N1infections.

\section{MATERIAL AND METHODS}

\section{General}

Mass spectra were measured on a JEOL JMS-AX500 spectrometer, Graduate School of Agriculture, Hokkaido University, Japan. NMR was recorded on a Bruker AM-500 FTNMR spectrometer, Graduate School of Agriculture, Hokkaido University, Japan. UV spectrophotometer (Shimadzu UV-240/ National Research Center/Egypt)

\section{Plant material}

Fresh leaves of $D$. cinerea were collected from Wadi Halfa, South Egypt, in April 2013. The plant was authenticated by Prof. Dr. S. Kawashty, Department of Phytochemical and Plant Systematics, NRC. A voucher specimen was deposited in the Herbarium of NRC (CAIRC, Cairo, Egypt).

\section{Extraction and isolation}

The shade dried leaves (450 gm) were extracted by percolation for $48 \mathrm{hrs}$ in $70 \%$ methanol. The extract was chromatographed on a polyamide 6S (Riedel-De-Haen AG, SeelzeHaen AG, SeelzeHanver, Germany) column (500 gm) (180 $\times 5 \mathrm{~cm}$ ) and eluted with $\mathrm{H}_{2} \mathrm{O} / \mathrm{MeOH}$ mixtures of decreasing polarities to yield four fractions (I-IV), which were individually subjected to column chromatography on sephadex LH-20
(Pharmacia Fine Chemicals, Uppsala, Sweden); using $50 \% \mathrm{MeOH}$ or n-butanol water saturated as an eluent, and/or preparative paper chromatography; using BAW (n-BuOH-HOAc- $\mathrm{H}_{2} \mathrm{O}$ 4:1:5, upper layer) or $15 \%$ acetic acid as an eluent. Compounds (1); $32 \mathrm{mg}$ and (2); $24 \mathrm{mg}$ were isolated and purified from fraction II, compounds (3); $76 \mathrm{mg}$, (4); 29 mg, (5); $41 \mathrm{mg}$, (6); $38 \mathrm{mg}$ and (7); $33 \mathrm{mg}$ were obtained pure from fraction III, finally fraction IV yielded compounds $(\mathbf{8}) ; 19 \mathrm{mg},(\mathbf{9}) ; 17 \mathrm{mg}$ and (10); $23 \mathrm{mg}$. Each isolated compound was purified using Sephadex LH-20 column. The structures were elucidated by chemical (partial and complete acid hydrolysis) and spectroscopic analysis (UV, ${ }^{1} \mathrm{H}$ and ${ }^{13} \mathrm{C} \mathrm{NMR}$, HMQC, HMBC, COSY and MS).

\section{Antiviral activity}

Madin-Darby Canine Kidney (MDCK) cells were maintained in the Center of Scientific Excellence for influenza viruses at the National Research Centre/Cairo/Egypt. The cells were propagated till confluence in multi-well plates. The highly pathogenic avian influenza (HPAI) virus A/Chicken/Egypt/M7217B/2013 (H5N1) used in the current study was isolated from the infected chickens in Egypt in 2013 and characterized at immunologic and molecular levels. MTT assay was used to determine the $\mathrm{LC}_{50}$ of the extract and clovamide according to the reported method (Mosmann et al., 1983). Briefly, the cells were cultured in 96 well-plates and incubated for $24 \mathrm{hrs}$ at $37^{\circ} \mathrm{C}$ in $5 \% \mathrm{CO}_{2}$. Then, they were treated with triplicates of the tested compounds. One day later, the supernatant was discarded and monolayers of cells were washed three times with sterile phosphate buffer saline. MTT solution was added to each well and incubated for $4 \mathrm{hrs}$ at $37{ }^{\circ} \mathrm{C}$. The formed formazan crystals in each well were dissolved in acidified isopropanol (200 $\mu 1)$. Absorbance of formazan solutions was measured at $\lambda \max 540 \mathrm{~nm}$ with $620 \mathrm{~nm}$ as a reference wavelength using a multi-well plate reader. The percentage of cytotoxicity compared to the untreated cells was determined as following: $\%$ of cytotoxicity $=[$ (Absorbance of cell without treatment - Absorbance of cell with treatment)/ Absorbance of cell without treatment] $x$ 100. The plot of $\%$ cytotoxicity versus sample concentration was used to calculate the concentration which exhibited $50 \%$ cytotoxicity $\left(\mathrm{TC}_{50}\right)$. Plaque reduction assay was used to determine the antiviral activity for both of the extract and clovamide at safe concentrations (Hayden et al., 1980).

\section{Antitrypanosomal activity}

Trypanosoma evansi (H3 strain, isolated from deer in Thailand) were provided by Dr. Onuma, Graduate School of Veterinary Medicine, Hokkaido University, Japan. Trypomastigote forms of the parasite $T$. evansi were maintained in HMI-9 medium supplemented with $20 \%$ heat-inactivated horse serum (SigmaAldrich/Germany). In vitro antitrypanosomal test was performed to determine the $50 \%$ inhibitory concentration $\left(\mathrm{IC}_{50}\right)$ on parasite growth for clovamide (Bawm et al., 2008). Briefly, tests were performed in a 96-well microtiter plate using clovamide and standard trypanocidal drug, diminazene aceturate (Sigma- 
Aldrich/Germany). Both of the standard and the tested compound were dissolved in dimethyl sulfoxide (DMSO). Three-fold serial dilutions were prepared in HMI-9 medium. Trypomastigotes of $T$. evansi were incubated in each well in the presence of three-fold serial dilutions of tested compound. The plates were incubated at $37{ }^{\circ} \mathrm{C}$ in $5 \% \mathrm{CO} 2$ atmosphere for $72 \mathrm{~h}$ and the number of motile parasites was counted using hemocytometer

\section{RESULTS AND DISCUSSION}

\section{Identification of the isolated compounds}

The application of different chemical and spectral techniques led to the isolation of ten compounds (Fig. 1). They were identified as; apigenin-7-O-apiosyl $(1 \rightarrow 2)$ glucoside $(\mathbf{1})(\mathrm{Li}$ et al., 1997), chrysoeriol-7-O-apiosyl $(1 \rightarrow 2)$ glucoside $(2)$ (Lin et $a l ., 2007)$ and the major compound clovamide (N-caffeoyl-LDOPA) (3) (Sanbongi et al., 1998), were isolated for the first time from the plant. Quercetin-3-O-rhamnopyranoside (4) (Zeid et al., 2009), myricetin-3-O-rhamnopyranoside (5) (Kassem et al., 2016), myricetin-3-O-glucopyranoside (6) (Zeid et al., 2009), quercetin3-O-glucopyranoside (7) (Zeid et al., 2009), myricetin (8) (Kassem et al., 2016), apigenin (9) (Marzouk et al., 2016) and kaempferol (10) (Marzouk et al., 2016) were previously reported to occur in the plant (Zeid et al., 2009).
Compounds (1-3) were isolated for the first time from the plant. Compound 3, the major phenolic constituents of $D$. cinerea was elucidated and full characterized by $1 \mathrm{D}$ and 2D NMR $(\mathrm{H}-\mathrm{H}$ COSY, HMQC and HMBC). The ${ }^{1} \mathrm{H}$ NMR spectrum showed two pairs of doublets at $\delta 6.41$ and 7.17 ppm exhibiting a coupling constant of $15.7 \mathrm{~Hz}$ assigned to $\mathrm{H}-7$ and $\mathrm{H}-8$, respectively, which indicate two olefinic protons and their stereochemistry in trans.

Four aromatic doublets $[\delta 6.91(1 \mathrm{H}, \mathrm{d}, J=2.0 \mathrm{~Hz}), 6.71$ $(1 \mathrm{H}, \mathrm{d}, J=8.0 \mathrm{~Hz}), 6.62(1 \mathrm{H}, \mathrm{d}, J=1.8 \mathrm{~Hz})$ and $6.57(1 \mathrm{H}, \mathrm{d}, J=8.0$ $\mathrm{Hz}]$ and two doublets of doublets $[\delta 6.79(1 \mathrm{H}, \mathrm{dd}, J=8.5,2.0 \mathrm{~Hz})$ and $6.44(1 \mathrm{H}, \mathrm{d}, J=8.0,1.8 \mathrm{~Hz})]$ corresponding to six protons, indicating the presence of an axial symmetry of the two aromatic rings.

The 1H NMR spectrum also showed two doublets of doublets at $\delta 2.89(1 \mathrm{H}$, dd, $J=18.5,5.0 \mathrm{~Hz})$ and $2.71(1 \mathrm{H}$, dd, $J=22.5,8.5 \mathrm{~Hz}$ ), due to the position in $\alpha$ of the asymmetric carbon $\left(C 7^{\prime}\right)$, which indicates the presence of one methylene unit. H-8' appeared as multiplet at $4.37 \mathrm{ppm}$ due to the presence of methyne group.

The $1 \mathrm{H}$ and 13C-NMR data together with the HMBC corelation of compound 3 (Table 1) are in a good accordance with those previously published data (Sanbongi et al., 1998). Therfore, compound 3 was identified as clovamide [N-(3',4'-dihydroxytrans-cinnamoyl)-3-(3,4-dihydroxyphenyl)-L-alanine].<smiles>[R20]c1cc(O)c2c(=O)cc(-c3ccc(O)c([R])c3)oc2c1</smiles><smiles>O=C(/C=C\c1ccc(O)c(O)c1)NC(Cc1ccc(O)c(O)c1)C(=O)O</smiles>

3<smiles>[R]c1cc(-c2oc3cc(O)cc(O)c3c(=O)c2OCc2ccco2)cc([R])c1Cl</smiles>

Figure 1: Chemical Structures of the isolated compounds from Dichrostachys cinerea 
Table 1: ${ }^{1} \mathrm{H}-\mathrm{NMR},{ }^{13} \mathrm{C}-\mathrm{NMR}$ and HMBC data of clovamide in DMSO- $d_{6}$

\begin{tabular}{|c|c|c|c|}
\hline H/C & ${ }^{1}$ H-NMR $\left(500\right.$ MHz, DMSO- $d_{6}, \delta$, ppm) & ${ }^{13} \mathrm{C}-\mathrm{NMR}\left(100 \mathrm{MHz}, \mathrm{DMSO}-\mathrm{d}_{6} \delta, \mathrm{ppm}\right)$ & HMBC \\
\hline 1 & - & 126.4 & - \\
\hline 2 & $6.91(1 \mathrm{H}, \mathrm{d}, J=2.0 \mathrm{~Hz})$ & 114.3 & $\mathrm{C}-4, \mathrm{C}-6, \mathrm{C}-7$ \\
\hline 3 & - & 144.8 & - \\
\hline 4 & - & 147.4 & - \\
\hline 5 & $6.71(1 \mathrm{H}, \mathrm{d}, J=8.0 \mathrm{~Hz})$ & 115.8 & $\mathrm{C}-1, \mathrm{C}-3$ \\
\hline 6 & $6.79(1 \mathrm{H}, \mathrm{dd}, J=8.5,2.0 \mathrm{~Hz})$ & 120.4 & $\mathrm{C}-2, \mathrm{C}-4, \mathrm{C}-7$ \\
\hline 7 & $6.41(1 \mathrm{H}, \mathrm{d}, J=15.7 \mathrm{~Hz})$ & 118.4 & C-2, C-6, C-9 \\
\hline 8 & $7.17(1 \mathrm{H}, \mathrm{d}, J=15.7 \mathrm{~Hz})$ & 139.5 & $\mathrm{C}-1, \mathrm{C}-7, \mathrm{C}-9$ \\
\hline 9 & & 165.2 & - \\
\hline $\mathrm{NH}$ & $8.1(1 \mathrm{H}, \mathrm{d}, J=8.0 \mathrm{~Hz})$ & - & - \\
\hline $1^{\prime}$ & & 128.7 & - \\
\hline $2^{\prime}$ & $6.62(1 \mathrm{H}, \mathrm{d}, J=1.8 \mathrm{~Hz})$ & 116.6 & C-4', C-6' \\
\hline $3^{\prime}$ & - & 145.6 & - \\
\hline $4^{\prime}$ & - & 143.7 & - \\
\hline $5^{\prime}$ & $6.57(1 \mathrm{H}, \mathrm{d}, J=8.0 \mathrm{~Hz})$ & 115.3 & $\mathrm{C}-1^{\prime}, \mathrm{C}-3^{\prime}$ \\
\hline $6^{\prime}$ & $6.44(1 \mathrm{H}, \mathrm{d}, J=8.0,1.8 \mathrm{~Hz})$ & 119.9 & $\mathrm{C}-2^{\prime}, \mathrm{C}-4^{\prime}$ \\
\hline \multirow[t]{2}{*}{$7^{\prime}$} & $2.89\left(1 \mathrm{H}, \mathrm{dd}, J=18.5,5.0 \mathrm{~Hz}, \mathrm{H}-7^{\prime} \mathrm{a}\right)$ & 38.5 & C-2', C-6', C-9 \\
\hline & $2.71\left(1 \mathrm{H}, \mathrm{dd}, J=22.5,8.5 \mathrm{~Hz}, \mathrm{H}-7^{\prime} \mathrm{b}\right)$ & & \\
\hline $8^{\prime}$ & $4.37(1 \mathrm{H}, \mathrm{m})$ & 54.4 & $\mathrm{C}-1^{\prime}, \mathrm{C}-9$ \\
\hline $9^{\prime}$ & - & 173.6 & - \\
\hline
\end{tabular}

\section{Antiviral activity}

The cytotoxicity of the extract and clovamide $\mathrm{LC}_{50}$ were found to be (30 and $68 \mu \mathrm{g} / \mathrm{ml}$ ), respectively. Both showed a remarkable virus inhibition activity against influenza $A$ virus (H5N1) infection up to $73 \%$ for the extract and $74 \%$ for clovamide at concentration $(20 \mu \mathrm{g} / \mu \mathrm{l})$. The pure compound clovamide showed higher inhibition rate than the extract at the used concentration.

\section{Antitrypanosomal activity}

Clovamide was also tested in vitro against $T$. evansi and showed a strong potential for antitrypanosomal activity with $\left(\mathrm{IC}_{50}=3.27 \mu \mathrm{g} / \mathrm{ml}\right)$ which compared well with the standard trypanocidal drug diminazene aceturate $\left(\mathrm{IC}_{50}=0.72 \mu \mathrm{g} / \mathrm{ml}\right)$. Although diminazene aceturate still show a stronger antitrypanosomal activity against $T$. evansi than clovamide, its fatal side-effects (Peregrine et al., 1993) together with the comparatively low toxicity of clovamide determined by the relatively high $\operatorname{LC}_{50}(68 \mu \mathrm{g} / \mu \mathrm{l})$ nominate the later as a promising safe compound for further in vivo investigation.

\section{CONCLUSION}

Ten phenolic compounds were identified from $D$. cinerea, among them; compounds 1-3 were isolated for the first time from the studied taxa. To the best of our knowledge, this is the first report for the antiviral and antitrypanosomal activities of clovamide, which showed remarkable activity against H5N1 influenza $\mathrm{A}$ virus and a strong trypanocidal activity against $T$. evansi nominating it as a relatively safe promising antitrypanosomal compound for further investigation.

\section{ACKNOWLEDGMENT}

The antiviral activity assay was performed at the Centre of Scientific Excellence for influenza viruses at the National Research Centre by Dr. Ola Bagato under supervision of Prof. Dr. Mohamed A. Ali. Antitrypanosomal activity assay was performed at Graduate School of Agriculture, Hokkaido University, Japan, by Dr. Khine Swe Nyunt.

Financial support and sponsorship: This research is funded by the National research centre, Cairo, Egypt; Project number 11011328.

Conflict of Interests: There are no conflicts of interest.

\section{REFERERNCES}

Atindehou KK, Schmid C, Brun R, Koné MW, Traore D. Antitrypanosomal and antiplasmodial activity of medicinal plants from Côte d'Ivoire. J. Ethnopharmacol. 2004; 90:221-227.

Aworet-Samseny RR, Souza A, Kpahé F, Konaté K, Datté JY. Dichrostachys cinerea (L.) Wight et Arn (Mimosaceae) hydro-alcoholic extract action on the contractility of tracheal smooth muscle isolated from guinea-pig." BMC complement Altern Med. 2011; 11:23

Bawm S, Matsuura H, Elkhateeb A, Nabeta K, Nonaka N, Oku $\mathrm{Y}$, Katakura K. In vitro antitrypanosomal activities of quassinoid compounds from the fruits of a medicinal plant, Brucea javanica.. Vet Parasitol. 2008; 158:288-294.

Droebner K, Ehrhardt C, Poetter A, Ludwig S, Planz O. CYSTUS052, a polyphenol-rich plant extract, exerts anti-influenza virus activity in mice. Antiviral research. 2007;7:1-10.

Elkhateeb A, Tosa Y, Matsuura H, Nabeta K, Katakura K. Antitrypanosomal activities of acetylated bruceines A and C; a structureactivity relationship study. J Nat Med. 2012; 66:233-240.

Hayden, F.; Cote, K.; Douglas, R. Plaque inhibition assay for drug susceptibility testing of influenza viruses. Antimicrob Agents Chemother. 1980; 17:865-870. 
Kassem ME, Ibrahim LF, Hussein SR, El-Sharawy R, El-Ansari MA, Hassanane MM, Booles HF. Myricitrin and bioactive extract of Albizia amara leaves: DNA protection and modulation of fertility and antioxidant-related genes expression.. Pharm Biol. 2016; 11:2404-2409.

$\mathrm{Li} \mathrm{TM}, \mathrm{Li}$ WK, Yu JG. Flavonoids from Artabotrys hexapetalus. Phytochemistry. 1997; 45: 831-833.

Lin LZ, Lu S, Harnly JM. Detection and quantification of glycosylated flavonoid malonates in celery, Chinese celery, and celery seed by LC-DAD-ESI/MS. J Agric Food Chem. 2007; 55:1321-1326.

Luckins AG. Trypanosoma evansi in Asia. Parasitol Today. 1988;4:137-142.

Marzouk, M.M., Hussein, S.R., Kassem, M.E.S., Kawashty, S.A., El Negomy, S.I.M. Phytochemical constituents and chemosystematic significance of Chrozophora tinctoria (L.) Raf. Nat Prod Res. 2016; 30(13):1537-41.

Mosmann, T. Rapid colorimetric assay for cellular growth and survival: application to proliferation and cytotoxicity assays. J Immunol Methods. 1983; 65:55-63.

Neondo JO, Mbithe CM, Njenga PK, Muthuri CW. Phytochemical characterization, antibacterial screening and toxicity evaluation of Dichrostachys cinerea. Int J Med Plant Res. 2012;1:32-37.

Peregrine AS, Mamman M. Pharmacology of diminazene: a review. Acta Trop. 1993; 54: 185-203.

Pleschka S, Stein M, Schoop R, Hudson JB. Anti-viral properties and mode of action of standardized Echinacea purpurea extract against highly pathogenic avian influenza virus (H5N1, H7N7) and swineorigin H1N1 (S-OIV). Virol. J. 2009; 6:197.
Sanbongi C, Osakabe N, Natsume M, Takizawa T, Gomi S, Osawa T. Antioxidative polyphenols isolated from Theobroma cacao. J Agric Food Chem. 1998; 46:454-457.

Tillement JP, Albengres E. Pharmacological approach to the rational use of cardiotonic heterosides. Coeur Med Interne. 1977; 16:239. 248.

Vijayalakshmi M, Periyanayagam K, Prabu SL. In vitro antilice activity of Dichrostachys cinerea (L.) Wight \& Arn. Int J PharmTech Res. 2010; 2:2210-2213.

Zeid AH, Hifnawy MS, Mohammed RS. Phenolic Compounds and Biological Activities of Dichrostachys cinerea L. Med Aromat Plant Sci Biotechnol. 2009; 3:42-49.

\section{How to cite this article:}

El-Sharawy RT, Elkhateeb A, Marzouk MM, Abd El-Latif RR, Abdelrazig SE, El-Ansari MA. Antiviral and antiparasitic activities of clovamide: the major constituent of Dichrostachys cinerea (L.) Wight et Arn. J App Pharm Sci, 2017; 7 (09): 219-223. 